\title{
Whose Gender Equality Counts? The Case of Russian Migrant Couples in Norway
}

\author{
Natalia Kukarenko ${ }^{1}$ \\ Northern (Arctic) Federal University, Arkhangelsk, Russia
}

\begin{abstract}
The article addresses the problem of "normalizing" migrants within a nation state by means of a gender system. The example of Russian immigrants in Norway shows how crossing a physical border moves people across different gender systems. In this transition migrants (re-)negotiate their gender identities and understandings of gender equality. At the same time, trying to integrate into the host society, they problematize the normalizing power of gender systems functioning in a particular society. The article is arranged in three parts starting with an overview of Russian migrants in Norway as a group. The second part describes different gender systems, which Russian immigrant couples cross. The third part shows how Soviet, Post-Soviet and Norwegian gender systems affect the experiences and expectations of Russian migrants in Norway and how gender intersects with nationality and a nation-state gender system. In conclusion, the potential for changing a nation-state gender system and integrating diversity is discussed.
\end{abstract}

Keywords: gender equality, gender systems, Russian migrants in Norway.

\section{Introduction: Crossing Borders, Changing Gender Systems}

Like many western countries today, Norway is facing increased immigration flows. Acknowledging itself as a multinational country, it has had to reshape the language of democracy and immigration policy focusing on the inclusion of diversity. On one hand, encouragement of cultural diversity challenges any uniformity or homogeneity associated with what it means to be Norwegian (Gullestad 2006; Berg, Flemmen and Gullikstad 2010) while creating an indirect demand on the "Others" to be the "same" and "like us". On the other hand, integration of diversity policies has led to debates on tolerance and tension between different cultural values, norms, rules (Okin 1999; Young 2007; Parekh 2008), and demands that differences be taken

\footnotetext{
${ }^{1}$ Corresponding author. Address: Natalia Kukarenko, Northern (Arctic) Federal University, Arkhangelsk, Russia. E-mail: n.kukarenko@narfu.ru
} 
beyond the binary oppositions of "superior/civilized-inferior/barbarian" cultures. In the context of these debates, gender equality has become a demarcation line between cultures, nationalities, and ethnicities setting them in a binary opposition of uncivilized/equal vs. them/barbaric/unequal. "Normalizing" logic is applied to immigrants and "locates" "them" as (non)compliant with the host society's values. At the same time, gender equality evolves into "a concept the main purpose of which is to maintain the sense of 'us' as a national community" (Holli 2003, 19). In Young's terms, a "funny inversion" happens to gender equality when it comes to the politics of cultural diversity and debates on tolerance: from being a marginal topic in public debates, it suddenly becomes a central and universal value (Young 2007, 87).

Norway is considered to be one of the most gender-equal countries in the world. Yet even Norway is confronted with the equality/diversity dilemma when the inclusion of migrants comes up as an issue (Lotherington 2008). The migrants and their behavioral patterns come to be measured against Norwegian norms in terms of how they comply with the "Norwegian" version of gender equality.

Immigrants from Russia started to arrive in Norway in larger numbers after the fall of the "iron curtain" and the ensuing collapse of the USSR. The circumstances of the early 1990s migration and the following debates led to stigmatization of Russians, both men and women, as well as to a general perception of them as "not understanding" the value of gender equality (Stenvoll 2002; Leontieva and Sarsenov 2003; Flemmen 2007).

This article addresses the problem of "normalizing" migrants within a nation state by means of a gender system. Taking the example of Russian immigrants in Norway, I show that when Russians cross the NorwegianRussian border, they also move across different gender systems. In this transition process, Russian migrants (re)negotiate their identities, understandings of gender equality, femininity, and masculinity. At the same time, while trying to integrate into the host society, they problematize the normalizing power of gender systems functioning in this particular society.

This article starts with an overview of Russian migrants in Norway as a group and the way empirical data for this study of migrations and gender was collected and analysed and then describes the different gender systems that Russian immigrant couples cross. The bulk of the analysis examines how Soviet, Post-Soviet, and Norwegian gender systems affect the current experiences and expectations of Russian migrants in Norway, and how, in their discussions on gender equality, gender intersects with nationality and a nation-state gender system. The conclusion considers how such nationstate gender systems can be changed to integrate diversity through providing spaces allowing migrants' self-expression. 


\section{Methodology}

Russian immigrants do not constitute the biggest migrant group in Norway, but Russian migration is distinctive. First, Russian migration is highly gendered with women making up almost $70 \%$ of all adult Russian immigrants (Nadim and Tveit 2009) who migrate to study, work, or, as in the majority of cases, get married (Lotherington and Fjørtoft 2007; Brækhus this volume). Second, Russian migrants have higher levels of education than other migrant groups and the Norwegian population generally (Daugstad 2008; Nadim and Tveit 2009). Third, the facial complexion of Slavic Russians makes it easier for them not to be taken as "others" at first glance. This puts them in a different position with respect to migrants of colour and to the majority population as "different whites." The constellation of education level, whiteness, and gender makes their situation in the Norwegian context particular. Lotherington and Flemmen give examples of Russian female immigrants finding themselves in the "in-between and nowhere" position: Norwegian immigration rules and the technicalities governing marriage migrants in the settlement process make Russian women dependant partners and subordinate citizens. They live in Norway but are not part of the society (Flemmen and Lotherington 2009). Recent studies on images of Russian women in the mass media in Norway in the 1990s show that Russian immigrants were not only categorized through nationality and gender but also that their sexuality was perceived as dangerous and threatening to Norwegian society and especially to its gender equality regime (Stenvoll 2002; Leontieva and Sarsenov 2003; Flemmen 2007).

Movement from Russia to Norway is limited by national and international regulations and allows long-term stay only for purposes of education (time limited), work (contract restricted), or family reunion/ marriage (Flemmen and Lotherington 2009; Brækhus in this volume). Large numbers of Russian marriage migrants are women who marry men with no immigrant background, and these women had predominantly lived in Russia before they entered Norway and got married (Daugstad and Sandnes 2008). Few Russian male migrants marry resident women, so they tended to marry women from the same national background (Flemmen and Lotherington 2009; Daugstad and Sandnes 2008).

This article uses empirical data based on semi-structured interviews with Russian-Russian couples residing in North Norway to explore and illustrate these dynamics. While the interview material does not allow the presentation of a general picture of Russian-Russian couples in Norway, it does allow examination of the specific situations and experiences described 
by informants and sheds light on their particular integration into Norwegian society.

There are not many Russian-Russian couples in Norway. Six couples agreed to be interviewed for the project; in four cases both spouses were present in the interviews, and in two cases only the wife was present. All the interviews were carried out in Russian. All the informants arrived from the northwest of Russia. All the respondents were recruited through the snowball method (Biernacki and Waldorf 1981; Heckathorn 1997) and recommendations from a network of personal contacts. The age of the respondents in this case-study is essential for an understanding of their mentality as they were all born in the Soviet Union. The youngest respondent (a woman) was twenty-four at the time of the interview. This means they were all raised and socialized within the Soviet gender system and its gender values and norms. Out of ten respondents only one woman and two men did not have a higher education diploma; instead they had professional education diplomas. In four cases, one of the spouses was invited to Norway as a specialist; in one case a woman came as a marriage migrant but later divorced and brought over a new husband from Russia; and in one case a man came on family reunion grounds as his mother had been married to a Norwegian man. In all cases, the informants said that one of the main reasons they moved to Norway and wanted to stay there was the wellbeing of their families, income stability, and a high standard of living.

The interviews with the Russian-Russian couples residing in Norway are of particular interest as their interaction with the majority society is in many respects different from those Russian migrants who have family relations with Norwegian residents. Lacking "native" door-openers within the family, they have to rely on other sources of information about Norwegian society, its public services and bureaucracy such as personal networks, language courses, and media information. The analysis in this chapter uses the theory of the gender system suggested by Yvonne Hirdman (1991) to show that a gender system not only produces power misbalances between genders, but also creates new forms of exclusion and new hierarchies within genders and in a society generally through ideology/ representations of that society and its values. The term "gender system" is used here to mean a combination of institutions and social interactions ascribing normative models and behaviour patterns to genders. A gender system maintains certain models of masculinity and femininity, gender ideology-structuring behaviour patterns, and expectations creating asymmetric power relations. 


\section{Gender Systems: Soviet Legacy, Norwegian Context}

The gender system of a nation state disciplines its citizens via gender ideology to perceive it as something "natural" and how being part of it creates the feeling of "belonging." The very same mechanism, when applied to immigrants, also "normalizes" them to affiliate with the state gender equality ideal if they want to become a part of the host society. In the USSR, the state became the main actor creating and maintaining the new gender system regulating relations between the state and its male and female citizens in the Soviet era. The state etacratic ${ }^{2}$ gender politics limited opportunities for individual agency. The Soviet gender system was based on a "gender contract" (Hirdman 1991) that involved both genders and intruded at all levels of institutional, social, and symbolic practices, including formal and informal rules, norms, and images defined by place, tasks, and roles of the genders in society.

The Soviet gender system applied a gender-neutral approach to the political sphere and constructed women and men as formally politically equal citizens denying existence of any gender differences. The emancipation project, however, was combined with the absence of actual equality: while they had de jure rights, people lacked actual or de facto rights (Aivazova 1998; Kukarenko 2000). The gender contract in Russia included gender stereotypes and maintained gender-marked roles, rights, and duties for citizens, placing women and men in different everyday realities with different opportunities, rights, and duties (Zdravomyslova and Temkina 2004; Kukarenko 2006). Men were placed in the public realm, while the contract between the State and Soviet women made the latter responsible for the family. Public gender-neutral practices thus did not preclude traditionalist expectations regarding gender behaviour. The normative masculinity and femininity patterns followed traditional lines when men were presented as warriors, defenders, and workers, and women were offered the option to be working mothers with active life positions (Aivazova 1998). Thus the position of Russian women was quite contradictory as they had greater freedom and more equality than women in most other countries, but views on women and their position in society were traditionalist (Temkina 1997).

The current post-Soviet gender system is characterized as neoliberal (Temkina 2004). The role of the state has diminished as has social provision and ideological support for the "working mother." Nevertheless, economic independence for women as "working mothers" is still mostly achieved though both maternity and work, provision for which has ceased to be a

${ }^{2}$ Zdravomyslova and Temkina (2004) define "etacratic" as a pro-statist politics supported by a particular regime of citizenship when all Soviet citizens are granted rights and obligations to be used by them only for building socialism and proving their loyalty to the government. 
civic duty for the State and is now either a matter of individual choice or a result of necessity.

At the same time, the Soviet legacy in post-Soviet Russia implies the acknowledgement that equality between men and women has been achieved, but continues to allow gender stereotypes. The recovery of "true" femininity and masculinity in Russian women and men was seen as part of the transition from Soviet socialism to a new capitalist Russia. In the postSoviet period, the mass media and politicians placed great emphasis on female specificity and differences in men's and women's "natural" missions. Part of the post-Soviet change was the presumed freeing of women from the compulsory duty to work and to be active in the public sphere. The problem, however, was that in reality, most of Russian families could not afford for women to stay at home. Nevertheless, the image of "true" femininity as developing its "nature" within the realm of the family and through care was one of the strongest messages sent to the public (Rotkirch and Temkina 1997; Zdravomyslova 2007). This image was constructed in contrast to the "false" Soviet idea of femininity. The Soviet way of understanding women's roles and missions was condemned as it was claimed to have deprived Russian women of their "true" feminine nature in the name of the State. The Soviet equality between men and women was also condemned as the Soviet state was accused of hypocrisy: the real reasons for introducing the most advanced gender reforms were purely economic, not of respect for individual freedoms and rights (Temkina 1997; Aivazova 1998, Kukarenko 2006). It is interesting that in this context women's “strong” role in the private sphere became the basis for their political and social activism. "Responsible motherhood" provided women with some access to public arenas, such as "soldiers' mothers" or "mothers of children with disabilities" (Zdravomyslova 2007).

The contradiction between the new neoliberal thinking and everyday reality has also led to the situation in which both Russian men and women, when assess whether their family practices are equal or not, describe it in terms of men "helping" women with the household and especially with reference to the kitchen (Kukarenko 2002). Thus the paradox is that women working for a salary is not perceived as a problem for family relations, but the active involvement of men in family and household chores results in their being characterised as "henpecked" and less masculine (Kukarenko 2007).

The Nordic welfare states, and Norway in particular, are considered to be woman-friendly states (Hernes 1987) because of the high numbers of women in politics and education, advanced gender equality legislation, developed systems of public child care and parental-leave schemes, all of which taken together facilitate women's integration into paid work. Since the 1970s, 
state feminism in the form of the institutionalization of gender equality has implied women-oriented policies and practices. In the 1970s, the predominant discourse in assessing the reforms for women was the universal breadwinner model, which posited sameness of men and women (Hernes 1987). Reality, however, showed that, despite success in politics and increased numbers of women in education, the labour market remained strongly gender segregated, the gender gap in wages continued to exist, and women were still responsible for most of the housework and care provision (Skjeie and Teigen 2005; Borchorst, and Siim 2008). In the 1990s, the strong women's political movement and feminist rhetoric of difference changed the articulation of the discourse of gender equality. The difference rhetoric shifted the focus from the "sameness" of men and women to recognition of the differences between the genders and the specificities of women's contribution, and, consequently, to equality of opportunity (Skjeie 1992).

Since the mid1990s, the mainstreaming of gender equality as a tool for integrating gender perspectives in all public policies has been systematically implemented in Norway, including in the form of gender budgeting (Rönnblom 2005). The recognition of differences between genders has also led to wider discussions about men's inclusion into care work and strategies aimed at changing men. The close link between family and gender equality policies, which sought to give both women and men equal opportunities to combine work and parenting, resulted in Norway's investments in improving conditions for families with young children. Norwegian parental leave schemes and day-care are considered to be among the best in the world, and in recent years, the focus has been on strengthening the role of fathers. To this end a paternity quota was introduced in 1993, reserving four weeks of the parental leave period for fathers. Although men had been entitled to paternity leave since the late 1970s, few had used it. However, the number of men taking advantage of the paternity quota is currently growing rapidly (Duvander, Lappegård and Andersson 2010).

Although Norway is called a "heaven for gender equality" concerns are still raised about gender discrimination and inequalities in economic decision-making, violence against women, prostitution, and the rights of immigrant women (United Nations 2003) Gender gaps still remain in paid work; “women still earn 86 per cent of a man's wage. Women make up 71 percent of the public sector and 34 percent of women work part-time, compared to 14 percent men" (Brother 2015) - all of which leaves Norwegian women with high-paid but mostly part-time jobs. What is more, Norway remains a country with a highly gender segregated labour market "with respect to both sectors and occupations" (European Commission 2013, 13). None of this is to criticise Norway for these shortcomings in implementing the ideals of gender equality, but rather to demonstrate that the gender 
system ideology encourages gender equality as a set of specific practices and the Norwegian gender system assesses immigrants according to this, the newest Norwegian "gender equality" ideals. The normalizing logics, implicit in any nation state, sets limits to diversity and accepts little tolerance of the differences of "others" (Young 2007). Thus this chapter seeks to contribute to the developing the integration of diversity policy within a nation state by shedding light on the complex intersections of gender equality, migration, nation-state gender systems, and diversity inclusion discourses.

\section{In-between Gender Systems}

Gender equality is a familiar concept to Russian immigrants coming to Norway. At the same time, gender equality is often presented as a particular mark and value of Norwegian society (Siim and Skjeie 2008). Family lifestyles and the practices of Russian-Russian couples in Norway are measured against it and, on the basis of these experiences, respondents in this study make claims about national differences, gender equality, femininity, and masculinity.

Interestingly, equality in the family has become a sign of "Russianness" or "Norwegianness." In all but one of the families interviewed, the men claimed that they live in a "matriarchy" with the wife being in charge and the leader, while the women said that they have equal relations and make a good team that is able to sort out any problems. The contradiction in the responses is interesting as the couples further explained that, first, it used to be this way back at home in Russia, but, second, they mentioned that life in Norway forced men to get more involved in household chores (especially if the wife had a job and the husband did not). Moreover, all the female respondents claimed that their family relations were equal and of the usual Russian type, while at the same time stressing that as a couple they were not typical of Russia.

Katya, 31: And we used to have a family in the Norwegian way back in Russia! The feeling in Russia was that he was "a rare bird", and here... At home his friends were constantly saying that he was a "henpecked husband"... Though his family resembles our family like we have now, it was not just his mother, I mean his father also cooks and everything. I mean he was already prepared in his family, though all his friends were saying... This did not bother him, but the main point - it is not true! Still I think he is more comfortable here in the sense that the lifestyle of our family is more Norwegian, not Russian. I mean "Russian" where they consider that the woman's place is in the kitchen. 
The informant, on the one hand, says that the family relations between her and her husband have not changed because even the family Katya's husband comes from used to be like their own family is now. On the other hand, the informant uses "Norwegianness" as an attribute to describe their family life, stressing the difference in their family setup from the average typical family in Russia. It seems that she uses "Russianness" and "Norwegianness" as markers: traditionalism versus modernity; patriarchy versus gender equality. This is where I argue that the legacy of the Soviet gender system, with its dubious and contradictory gender roles, has an effect. As I see it in the passage above, Katya actually says that "his friends" do not question women having paid work, but they do make an issue of a man entering the kitchen and see it as a sign of male subordination. The image of the "kitchen" in Russian culture is exclusively and self-evidently connected to the private sphere and is seen as a predominantly "female" domain. For Russian women, seeing a man in the kitchen symbolizes actual gender equality in family life and relations.

The interviews show that moving to Norway also involved a process of changing as couples reflected on the effects of living in Norway on their relations within the family. Negotiations and discussions within families on equality in the division of tasks, in fact, took a new direction in Norway. In all the families, both partners were in waged work back in Russia. In Norway, only one couple arrived with jobs waiting for both partners from day one. Femininity and masculinity, the naturalness of women's expertise concerning house, children, and male participation in housework as being conditioned on his main work and willingness to help - all of this was challenged in the process of adaptation to a new living reality. Women's waged work and careers are still never an issue of a discussion. The attitude to men's participation in the housework and care provision seemed to be rationalized in the light of two major circumstances. First, change in routines, duties, and obligations happened in all of the couples' daily practices as a result of their moving to Norway. Second, they experienced the influence of Norwegian gender equality ideology as a very strong public issue.

Coming to Norway was a very serious change in itself. A new welfare system, new language, different culture - all affected small daily routines. In all couples, irrespective of who had the job first, the second partner immediately started looking for employment too, meanwhile taking the main responsibility for the household chores. This is where female respondents state that their couples became real teams in Norway due to the circumstances of their new life. 
Nastya, 36: On many, many things it is Igor who decides. On many it is me who makes decisions. We are like a team, everything solves itself, smoothly. But it was like that back at home. We used to live in a twelve-meter room in a hall of residence. We got used to each other then.

Igor, 36: Yes, if there is something... We both understand this is not worth quarrelling about. We always try to work things out by discussing them, looking for solutions....

At the time of the interview this couple had lived in Norway for two years with their daughter, who had been born in Russia. They both came as specialists with the same educational background. They claim that without the help of their Norwegian friends, their life would have been harder as they had many things explained to them and helped with a lot of practical issues. Later on they also became acquainted with other Russians living in Norway who served as further sources of information about Norwegian society and the practicalities of living there. At the time of the interview, they were both taking language courses and had participated in a summer school where they studied the Norwegian language and culture.

Family wellbeing and harmony at home became the driving arguments for men's greater involvement in family life. What is more interesting is that some Russian men said that they did not consider increased involvement in housework as a sign of them being deprived of their masculinity, but that still, the position of house-husband was unacceptable to all of them. Regarding the female respondents, like Katya above, they all stated that their husbands were different from the majority of Russian men initially.

At the same time, female informants stated that loving and respectful relations were of the utmost significance for equality. The images and stories of "good" Russian husbands are constructed on the border of traditional and modernized men. The "good" ones are represented as civilized, democratic, tender, helpful. They are different from "other" Russian men who are traditional machos. Most women-informants consider living with traditionalist men unacceptable and the relations in such marriages are perceived as lacking respect and freedom and forcing women into the position of serving men.

While stating that "good Russian husbands" are not like Norwegian, or more generally any foreign men, because they all lack (cross-)cultural understanding, Russian women-respondents articulated the view that the greatest value of Norwegian men lay in their active involvement in childcare.

Marina, 32: Have you seen their fathers who come to the University with baby prams; they bring babies to their moms for breast- 
feeding... I think to be a woman in Norway is very beneficial... if you are a woman - you are already officially good, "exclusive"! I think it is the general mentality, although perhaps not all Norwegians think the same. Of course, the state and its policies demand that a certain number of women are to be directors, politicians or something else. From time to time I hear Norwegians, men, when they talk, they say, "Oh she is stupid, but because she is a woman we had to employ her!" I mean that there inside they do not completely agree. Still it is all so different from Russia. In Norway even those men who are not so much happy with the way women are in Norway, nevertheless, they do not treat women as badly as men in Russia do.

Speaking of professional skills, women will never be equal to men, because, I do not know but she is a female. She has different instincts, children anyway... I do not know how to say that....

This part of the interview serves as an example of being in-between different gender systems in experiencing the transformations of masculinity and femininity they dictate. Marina was the one in her family who got the job offer in Norway and took her husband and daughter with her. Her husband spent almost a year as a house-husband before he got his first job in Norway as a low-skilled worker. Their communication with Norwegians is mostly restricted to working contexts and meetings with other parents at their daughter's kindergarten.

In this part Marina articulates her understandings of both masculinity and femininity. Making claims for women's natural mission and professional incompetence, Marina, on the one hand, articulates the stereotypes inherited from the Soviet/post-Soviet gender system with women being traditionally responsible for care work, while, on the other hand, her real life situation contradicts her statements. Her life situation forces her to be a "breadwinner" while her husband has to do the care work, and the inherited images of "true" femininity make her uncomfortable with both their current roles. At the same time because of this confusion she has developed new markers of gender equality and become sensitive to the issue in new ways. In fact it is not only Marina who notices that men in Norway take parental leave and bring babies for feeding to mothers who continue their studies at the University. Both female and male respondents mentioned that, unlike in Russia, men in Norway spent a great deal of time with children and family, and, because it is a general practice accepted in society, they do not look any less masculine to the Russian immigrant women and men, but are accorded appreciation and respect for it.

In her interview, Marina also discusses the importance of the gender equality issues for Norwegian society and the impact of the gender equality policies on the situation of women. At the same time, she claims that 
attitudes and practices concerning gender equality vary in Norwegian society and among Norwegian men in particular, despite a very strong public gender equality discourse. She actually says that there is a difference between the ideal and everyday reality in Norwegian society that allows ambivalent attitudes toward the Norwegian gender equality ideal on the level of attitudes and everyday practices.

As mentioned above there is extensive research showing that the Norwegian gender system, although the most advanced in many respects, is not perfect or fully achieved. More than that, the normative gender equality ideal is understood and practised differently by individuals, and the way couples negotiate it inside the family quite often depends on their relations and attitudes to each other, perceptions of fairness, and respect, number of children in the family, level of education of partners, level of family income, etc. (Bernhardt, Noack and Lyngstad 2008; Jakobsson and Kotsadam 2010). What is of relevance for this analysis, however, is that the Russian respondents articulated stereotypes that they have about Norwegian gender equality on the level of assumptions.

Vera, 35: Women are financially independent here and in Russia... The general attitude is like she is a thing. Most of the men in Russia are chauvinists.... Norway is a strong country because they respect women.

Misha, 36: So why don't you live like a Norwegian woman?

Vera: What do you mean?

Misha: I mean that you criticize Russia but at the same time you do not want the equality like they have at home. You remember we said that...the attitude between a man and a woman here, it is like between two men, you do not want me to treat you like Norwegians: like a man to a man.

Vera: But that is why I am not married to a Norwegian man.... Anyway I do not think it is such a privilege to have the door held for me when I am going through it.

Misha and Vera got acquainted when Vera visited Murmansk. At the time of the interview, Vera had lived in Norway for eleven years, arriving via marriage with a Western man who worked in Norway and from whom she was divorced after some years. During this first marriage, Vera learnt the Norwegian language, started to get a Norwegian B.A. (since her higher education diploma was not approved by the Norwegian authorities), was granted permanent residence, gave birth to a child, and got a job. For Vera' husband Misha, it is also a second marriage. He sends money and clothes to his two children from his first marriage in Russia. At the time of the interview Misha had lived in Norway for five years and the couple had a 
daughter in Norway. His professional technical education had not been approved at the time of the interview because he had a problem figuring out which authority should approve his diplomas. He was unemployed for quite a long time and in order to make ends meet instead of continuing to "fight" the system, he started to work as a semi-skilled worker, a handyman.

They claimed that as a couple they do not have many Norwegian friends, but Misha in his capacity of handyman visits different houses. He is critical of what he observes in the families as "it is not clean" in the houses with "many clothes and things on the floors," etc. All of this makes him uneasy at work, as in in one place where there was female underwear lying on the floor he perceived it a sign of both disrespect toward outsiders and to him as a man personally because the employers knew that "the handyman booked" was a man.

The vision of Norwegian gender equality that Russian immigrants articulate is that it is about the "sameness" of women and men in every respect, issue, or arena. Even though the gender system in Norway is seen as positive and beneficial both for women and society itself, the ideology of gender equality is experienced as strong, Russian immigrants see that practices of equality in Norwegian society vary, and they are critical of the gender system for being a very radical project aimed at eliminating all differences between men and women. Vera's comments are interesting here as, in her statements, we can observe how gender stereotypes about traditional femininity and masculinity clashed with the new possibilities offered by the Norwegian gender system. In fact, both Misha and Vera say, in slightly different ways, that for them it is natural for women to take responsibility for housework. For Misha, expertise and responsibility for running the house is as an integral part of being a woman. If they do not perform this function, women become masculinised for him. Vera says that she did not marry a Norwegian man because she does not want the "sameness" attitude. Her understanding of the link between femininity, masculinity, and gender equality is confused, but at the same time she does actually question why a person cannot have the best from different gender systems. It is exactly on this point that she is confronted by her husband. The Russian gaze is also gendered in its views of gender equality within Norwegian society.

Russian couples cross borders of states, cultures, and gender systems, and that is why what they actually negotiate in their families is experiences of being/living in the Norwegian society that are the result of exposure to the Norwegian gender system ideology and control. The peculiarity of their position is being in-between gender systems, in-between national cultures: they live in Norway but they do not experience themselves as "Norwegians." They do not feel comfortable any longer with the Russian 
gender system, and femininities and masculinities maintained by that system, but they still have that "baggage" with them. They feel that they are expected to do a "mimetic performance" of a "Norwegian" gender equality ideal with which they do not totally affiliate. Their "being on the margin" position (Braidotti 1994) allows them to see positive and negative features in all gender systems they have had experiences of, and, like Vera does, to actually question the necessity of choosing "either/ or" of the Russian and/or Norwegian gender systems. Vera and Misha combine practices that they both feel comfortable with as a couple. Thus, this last example shows that immigrants are situated in a position from which they, if being allowed, can challenge the nation-state gender system, and, consequently, transform it.

\section{Conclusion: National Gender Systems as Traps Between Diversity and Homogeneity?}

A number of recent studies on migration have called attention to the complexity of the impacts of migration, diversity inclusion, and gender equality policies on the situation of those on the move (Passerini 2007). In the context of Nordic countries, critical researchers have pointed out a sophisticated tendency in gender equality and ethnicity research to distance those countries' pasts from historical colonialism, to stress the homogeneity of their societies, and to present Nordic countries as having achieved gender equality (Gullestad 2006; Siim 2007; Flemmen and Lotherington 2009; Mulinari et al. 2009).

Gender equality functioning as a discourse and as a practice (or a set of practices) creates different expectations and allows different possibilities for native citizens and immigrants. Immigrants are confronted with the ideal and are required to interiorise it in a way the native population is never asked to (Gressgård and Jacobsen 2003; Lotherington 2008). At the same time it is important to keep in mind that a gender system not only produces power misbalances between genders, but also creates new forms of exclusion and new hierarchies within genders and in a society generally through ideology/representations of that society and its values. So both women and men experience the "normalizing" power of certain gender systems on their behaviour and choices irrespective of whether or not they cross borders.

Showing the impact of the Norwegian gender system on Russian immigrant couples' self-perceptions in Norwegian society is important because the peculiarity of situation of the Russian-Russian couples in Norway lies in the fact that their interaction with the majority society differs from the situation of immigrants in mixed marriages where one partner is 
Norwegian. Without a "native" door-opener within the family, they have to rely on available public sources of information in shaping their knowledge of Norwegian society, their visions, experiences, and understandings of what it means to be Norwegian. Furthermore, unlike refugees who are able to obtain useful knowledge about the everyday functioning of Norwegian society through refugee introduction programmes, Russian immigrants, if they intend to stay in Norway, are obliged to take courses in the Norwegian language and culture in order to do so. Thus, language courses, the internet, and social networks of Russian and Norwegian friends and colleagues were mentioned in the interviews as the most important sources of information about Norwegian society and Norwegian gender equality.

Gender system ideology promotes gender equality as a set of "certain" practices, and the Norwegian gender system assesses Russian immigrants according to the Norwegian "gender equality" ideal. This produces complex intersections of gender equality, migration, and diversity inclusion discourses. Immigrants are expected to follow feminine and masculine roles, modes of behaviour, and expectations that are shaped by the Norwegian state through its gender system. The nation-state gender system, applied to immigrants, limits their right to be different and actually expects them to choose the host society values, gender roles, and behaviour and actively affiliate with them. At the same time, this does not happen to native citizens who have the right to act out their individuality through affiliating or deviating from the "Norwegian" gender equality ideal in a variety of everyday practices, without admitting it in front of the eyes of "others." This happens because of the two simultaneous moves made by the Norwegian state: firstly, as a multicultural society, Norway tries to integrate diversity, but, secondly, it also promotes values, such as gender equality, as essential to Norwegian society. Taking the latter action, any nation state actually falls into the trap of homogeneity - diversity as "gender equality" becomes the constitutive element of the national community.

Gender systems are not rigid. However, it is possible to say that the history of Norwegian gender equality shows that it is a continuous process of creating gender hierarchies despite all the significant reforms for women. At the same time, it also shows that gender systems and contracts are subject to negotiation, renegotiation, and change. Through negotiation, gender inequalities linked to nationality/ethnicity within households, communities, the market, and the state are challenged. These negotiations might result in cooperation or in conflict, depending on the willingness of the participants to cooperate or escalate antagonism.

When social, political, cultural, and economic rules change, the gender system creates new segregations and hierarchies in society. Therefore, a gender system in itself is open to intervention and change if and when 
various actors have the right to question it (Asiimwe 2009). The nation state, articulating itself through national values, will always end up by excluding and/or assimilating someone. Norway as a multicultural country and Norway as a country of and for Norwegians are two different and opposite projects for understanding and planning the future. A diverse society is possible only when "others" have a place and a voice (Braidotti 2007; Siim and Skjeie 2008). This in turn suggests the urgency of creating new ways of defining participation and public spaces, a different way of constructing the collective social imaginary (Taylor 2003) that permits various forms of belonging, is inclusive of "other" lifestyles and participation, and yet at the same time allows the "normalizing" power of any gender system to be questioned. 


\section{Acknowledgements}

This article is based on the data from the research project "Diverse Equality in the Family Sphere? The Effects of Norwegian Diversity and Equality Policies" funded by the Research Council of Norway (2006-2007) but was prepared for publication within the TUAQ-network cooperation between Canada, Norway, Russia, and Sweden.

\section{References}

Aivazova, Svetlana. 1998. Russkie zhenschiny v labyrinte ravnopraviya: ocherki politicheskoi teorii $i$ istorii [Russian Women in the Equality Labyrinth: essays in Political Theory and History]. Moskva: RIK Rusanova.

Asiimwe, Florence Akiiki. 2009. Gender Dynamics in Homeownership: A Gender System and Contract Theoretical Framework for Analysing Gender Inequality in Homeownership in Urban Uganda. International Journal of Social Inquiry 2 (2): 75-104.

Berg, Anne Jorunn, Flemmen, Anne Britt and Gullikstad, Berit. 2010. Innledning: Interseksjonalitet, flertydighet og metodologiske utfordringer [Introduction: Intersectionality, Multiplicity and Methodological Challenges]. In Anne Jorunn Berg, Anne Britt Flemmen and Berit Gullikstad (eds.). Likestilte norskheter: om kjønn og etnisitet [Equal Norwegiannesses: On Gender and Ethnicity]. Trondheim: Tapir akademisk forlaget, 11-37.

Bernhardt, Eva, Noack, Turid and Lyngstad, Torkild Hovde. 2008. Shared Housework in Norway and Sweden: advancing the gender revolution. Journal of European Social Policy 18 (3): 275-288.

Biernacki, Patrick and Waldorf, Dan. 1981. Snowball Sampling Problems and Techniques of Chain Referral Sampling. Sociological Methods \& Research 10 (2): 141-163.

Borchorst, Anette and Siim, Birte. 2008. Woman-Friendly Policies and State Feminism: Theorizing Scandinavian Gender Equality. Feminist Theory 9 (2): 207-224.

Brækhus, Hege. (in this issue). Transnational Marriages in the North - Legal Issues Regarding Russian Women Married to Norwegian Men.

Braidotti, Rosi. 1994. Nomadic Subjects: Embodiment and Sexual Difference in Contemporary Feminist Theory. New York: Columbia University Press.

Braidotti, Rosi. 2007. On Becoming Europeans In Luisa Passerini, Dawn Lyon, Enrica Capussotti, and Ioanna Laliotou (eds.). Women Migrants from East to West: gender, mobility and belonging in contemporary Europe. Oxford-New York: Berghahn Books, 23-44.

Brother, Mona Elisabeth. 2015. Gender Equality in Norway: Progressive Policies and Major Challenges. The Huffington Post. 5 May. 
http://www.huffingtonpost.ca/mona-elisabeth-brother/gender-equalitynorway_b_6809300.html (Accessed 2015-05-05).

Daugstad, Gunnlaug and Sandnes, Toril. 2008. Gender and Migration. Similarities and disparities among women and men in the immigrant population. Statistics Norway, Reports 2008/10. Oslo: Statistics Norway.

Duvander, Anne Zofie, Lappegård, Trude and Andersson, Gunnar. 2010. Family policy and fertility: fathers' and mothers' use of parental leave and continued childbearing in Norway and Sweden. Journal of European Social Policy 20 (1): 45-57.

European Commission. 2013. The current situation of gender equality in Norway - Country Profile 2013.

http://ec.europa.eu/justice/genderequality/files/epo_campaign/131014_c ountryprofile_norway.pdf (Accessed 2017-08-13).

Flemmen, Anne Britt and Lotherington, Ann Therese. 2009. Transnational Marriage Migration. Russian-Norwegian Encounters. Saarbrücken: VDM Verlag Dr. Müller.

Flemmen, Anne Britt. 2007. Russiske kvinner i nordnorske aviser minoretets- og majoritetskonstruksjoner [Russian Women in North Norwegian Newspapers - minority and majorityconstructions]. Tidsskrift for kjønnsforskning [Journal of Gender Research] 1: 37-53.

Gressgård, Randi and Jacobsen, Christine M. 2003. Questions of Gender in a Multicultural Society. NORA-Nordic Journal of Women's Studies 11 (2): 6977.

Gullestad, Mariann. 2006. Plausible Prejudice. Everyday experiences and social images of nation, culture and race. Oslo: Universitetsforlaget.

Heckathorn, Douglas D. 1997. Respondent-Driven Sampling: A New Approach to The Study of Hidden Populations. Social Problems 44 (2): 174-199.

Hernes, Helga. 1987. Welfare State and Woman Power. Essays in State Feminism. Oslo: Norwegian University Press.

Hirdman, Yvonne. 1991. The Gender System. In Tayo Andreasen, Anette Borchorst and Drude Dahlerup (eds.). Moving On: New Perspectives on the Women's Movement. Aarhus: Aarhus University Press, 187-207.

Holli, Anne Maria. 2003. Discourse and Politics for Gender Equality in Late Twentieth Century Finland. Acta Politica 23. Helsinki: University of Helsinki.

Jakobsson, Niklas and Kotsadam, Andreas. 2010. Do attitudes towards gender equality really differ between Norway and Sweden? Journal of European Social Policy 20 (2): 142-159.

Kukarenko, Natalia. 2000. Ravenstvo mezhdu polami v nazionalnom kontekste. [Equality Between Sexes in the National Context. Feminist Contribution to the Concept of Equality]. In Zhenskie Miry'99: Zapadnyi 
opyt i gendernye issledovaniya $v$ Rossii [Women's Worlds'99: Western Experience and Gender Research in Russia]. Ivanovo: Ivanovo State University, 35-49.

Kukarenko, Natalia. 2002. Rural Women and Men in Arkhangelsk Region: Coping Strategies with Marginalization. In Taking Wing Conference Report. Helsinki: Reports of the Ministry of Social Affairs and Health, 8294.

Kukarenko, Natalia. 2006. Construction of Gender Equality in Soviet and Post-Soviet Russia. In Mare Rantaniemi and Kyosti Kurtakko (eds.). Reverberations from the Barents research and Cooperation (Papers from the seminars and study trips organized by the Barents Specialists Project during 2004-2005). Rovaniemi: University of Lapland, 59-72.

Kukarenko, Natalia. 2007. Normative Masculinity and Men's Practices in Russia. In Marit Anne Hauan, (ed.). Maskuliniteter i nord [Masculinities in the North. Tromso: University in Tromso. Kvinnforsks skriftserie [Women's Studies Occasional Paper] 6, 97-110.

Leontieva, Alexandra and Sarsenov, Karin. 2003. Russiske kvinner i skandinaviske medier [Russian Women in Scandinavian Media]. Kvinneforskning [Women's Studies] 2: 17-31.

Lotherington, Ann Therese and Fjørtoft, Kjesti. 2007. Russian women immigrants in North Norway. In Bjørn Hvinden and Håkan Johansson (eds.). Citizenship in Nordic Welfare States: Dynamics of Choice, Duties and Participation in a Changing Europe. New York: Routledge, 112-124.

Lotherington, Ann Therese. 2008. Over grensen. Konstrukjoner av likestilling og norskhet i russisk/norske familier [Beyond borders. Construction of equality and Norwegianness in Russian-Norwegian families]. Tidsskrift for kjønnsforskning [Journal of Gender Research] 32 (1): 6-20.

Mulinari, Diana, Keskinen, Suvi, Irni, Sari and Tuori, Salla. 2009. Introduction: Postcolonialism and the Nordic Models of Welfare and Gender. In Suvi Keskinen, Salla Tuori, Sari Irni and Diana Mulinari (eds.). Complying with colonialism: gender, race and ethnicity in the Nordic region. Aldershot: Ashgate, 1-16.

Nadim, Marjan and Tveit, Marianne. 2009. En fot innenfor? Integrering og samfunnsdeltakelse blant kvinner som har innvandret til Norge gjennom ekteskap med en norsk mann [One Leg in? Integration and Participation in the Society Among Women Who Migrated to Norway Via Marriage with a Norwegian Man]. Fafo-rapport 19. http://www.fafo.no/pub/rapp/20109/20109.pdf (Accessed 2015- 06-08).

Okin, Susan Moller. 1999. Is Multiculturalism Bad for Women? Princeton, New Jersey: Princeton University Press. 
Parekh, Bhikhu. 2008. A New Politics of Identity: Political Principles for an Independent World. New York: Palgrave Macmillan.

Passerini, Luisa, Lyon, Dawn, Capussotti, Enrica and Laliotou, Ioanna. 2007. Editor's Introduction. In Luisa Passerini, Dawn Lyon, Enrica Capussotti and Ioanna Laliotou (eds.). Women Migrants from East to West: gender, mobility and belonging in contemporary Europe. Oxford-New York, Berghahn Books, 1-20.

Rönnblom, Malin. 2005. Letting Women in? Gender Mainstreaming in Regional Policies. NORA: Nordic Journal of Women's Studies 13 (3): 164-174. Rotkirch, Anna and Temkina, Anna. 1997. Soviet Gender Contracts and Their Shifts in Contemporary Russia. Idantutkimu 4: 6-24.

Siim, Birte. 2007. The Challenge of Recognizing Diversity from the Perspective of Gender Equality: Dilemmas of Danish Citizenship. Critical Review of International Social and Political Philosophy, Special Issue Contesting Citizenship. Comparative Analyses 10 (4): 491-511.

Siim, Birte and Skjeie, Hege. 2008. Tracks, intersections and dead ends: Multicultural challenges to state feminism in Denmark and Norway. Ethnicities 8 (3): 322-344.

Skjeie, Hege and Teigen, Mari. 2005. Political Constructions of Gender Equality: Travelling towards a gender balanced equality. NORA: Nordic Journal of Women's Studies 13 (3): 187-197.

Skjeie, Hege. 1992. Den politiske betydningen av kjønn [The political meaning of gender]. Institute for Social Research Report 92:11. Oslo: Institute for Social Research Report.

Stenvoll, Dag. 2002. From Russia With Love? Newspaper Coverage of CrossBorder Prostitution in Northern Norway 1990-2001. The European Journal of Women's Studies 9 (2): 143-162.

Temkina, Anna. 2004. Nazionalnyi gendernyi poryadok: postsovetskie transformazii [National Gender Order: Post-Soviet Transformations]. In Irini Savkina, Grigoryi Uspenskyi and Valentina Uspenskaya (eds.). Gender po-russki: pregrady i predely [Gender in a Russian Style: Barriers and Limitations]. Tver: Feminist Press, 163-186.

Temkina, Anna. 1997. Russia in Transition: The Case of New Collective Actors and New Collective Actions. Helsinki: Kikimora Publications, 1997.

Taylor, Charles. 2003. Modern Social Imaginaries. Durham: Duke University Press.

United Nations. 2003. Norway Called 'Haven for Gender Equality' as Women's Anti-Discrimination Committee Examines Report on Compliance with Convention.

http://www.un.org/News/Press/docs/2003/wom1377.doc.htm (Accessed 2014-09-09). 
Young, Iris Marion. 2007. Structural Injustice and the Politics of Difference. In Anthony Simon Laden and David Owen (eds.). Multiculturalism and Political Theory. Cambridge: University Press, 60-88.

Zdravomyslova, Elena and Temkina, Anna. 2004. Gendernoe grazhdanstvo i sovetskii etakraticheskii poryadok [Gendered Citizenship and Soviet Etacratic Regime]. In Sergey Vasiliev (ed.). Aktualnye problemy transformazii sozialnogo prostranstva [Contemporary Issues of Social Space Transformation]. St.Petersburg: Leontievskii Zentr, 322-355.

Zdravomyslova, Elena. 2007. Soldiers' Mothers Fighting the Military Patriarchy: Re-invention of Responsible Activist Motherhood for Human Rights' Struggle. In Ilse Lenz, Charlotte Ulrich and Barbara Fersch (eds.). Gender Orders Unbound? Globalisation, Restructuring and Reciprocity. Opladen and Farmington Hills: Barbara Budrich Publishers, 207-226.

\section{Notes on contributor}

Natalia Kukarenko (PhD in Social Philosophy/ kand.filos.nauk) is currently a Vice-rector for Strategy and Cooperation at Northern (Arctic) Federal University (NArFU, Arkhangelsk, Russia) and an Associate Professor at Philosophy and Sociology Department, Higher School of Social Sciences, Humanities and Intercultural Communication, NArFU. As a researcher, her interests cover such topics as justice theories, gender studies and human diversity. She is the author of over 70 publications (articles, book chapters, monograph) in Russian and foreign languages. 